Jurnal Keperawatan Silampari

Volume 2, Nomor 1, Desember 2018

e-ISSN: 2581-1975

p-ISSN: 2597-7482

DOI: https://doi.org/10.31539/jks.v2i1.14

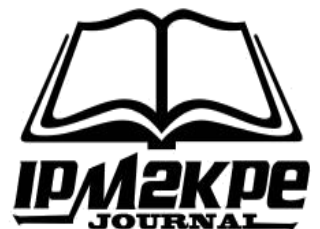

\title{
PERBEDAAN EFEKTIVITAS SENAM OTAK TERHADAP PENINGKATAN FUNGSI KOGNITIF ANTARA LANSIA LAKI-LAKI DAN PEREMPUAN
}

\author{
Fatsiwi Nunik Andari ${ }^{1}$, Muhammad Amin ${ }^{2}$, Yeta Fitriani ${ }^{3}$ \\ Program Studi Ilmu Keperawatan, Universitas Muhammadiyah Bengkulu 1,3 \\ Program Studi Kesehatan Masyarakat, Universitas Muhammadiyah Bengkulu ${ }^{2}$ \\ afatsiwi@yahoo.com ${ }^{1}$
}

\begin{abstract}
ABSTRAK
Penelitian ini bertujuan untuk mengetahui perbedaan fungsi kognitif antara lansia lakilaki dan perempuan setelah dilakukan intervensi senam otak pada lansia dengan gangguan fungsi kognitif. Metode yang digunakan dalam penelitian ini adalah experiment,yaitu Quasi experimentwithpre and posttest design. Hasil analisis data penelitian menunjukkan bahwa ada perbedaan fungsi kognitif antara lansia laki-laki dan perempuan sesudah diberikan intervensi senam otak dengan $\mathrm{P}$ value $=0,025$. Simpulan, ada perbedaan efektivitas senam otak terhadap peningkatan fungsi kognitif antara lansia laki-laki dan perempuan. Senam otak lebih efektif untuk peningkatan fungsi kognitif pada lansia laki-laki.
\end{abstract}

Kata Kunci : Fungsi Kognitif, Lansia, Senam Otak

\section{ABSTRACT}

The purpose of this study was to determine differences in cognitive function between men and women of elderly after being given brain gym intervention in patients with cognitive impairment. This research used experiment method, using Quasi experiment design with pre and posttest design. The results showed that there was a difference of cognitive function between men and women of elderly after giving brain exercise intervention with $P$ value $=0,025$. Conclusion, there was a difference in the effectiveness of brain gym on improving cognitive function between men and women of elderly. Brain gym is more effective for improving cognitive function in elderly men.

Keywords :Brain Gym, Cognitive Function, Elderly 


\section{PENDAHULUAN}

Menua merupakan suatu proses yang berkelanjutan dan berlangsung secara alami sejak manusiadilahirkan sampai menua. Proses ini berlangsung padasemua makhluk hidup termasuk manusia (Azizah, 2011). Menua diidentikkan dengan cirriciri berupa kemunduran fungsi biologis tubuh yang tampak sebagai penurunan kondisi fisik, seperti kulit yang tidak lagi kencang, adanya keriput, rambut banyak yang memutih, gigi yang tanggal serta terjadi penimbunan lemak utamanya pada bagian abdomen dan panggul.Penurunan lainnya adalah dalam hal berpikir seperti pikun,disorientasi ruang, tempat, dan waktu serta sulituntuk menerima hal-hal yang baru (Maryam, 2011).

Jumlah lansia diseluruh dunia dengan rentang usia 60 tahun berjumlah \pm 625 juta dan diprediksikan di tahun 2025 sekitar 1,2 milyar (Nugroho, 2012). World Health Organization (WHO) dalam Kementerian Kesehatan Republik Indonesia (2013) menjelakan bahwa jumlah lansia di Indonesia di tahun 2020 nanti berjumlah 28,8 juta orang atau sekitar 11,34\%, pada tahun 2025 sebanyak 1,2 milyar dan pada tahun 2050 meningkat menjadi 2 milyar. Gangguan fungsi kognitif sangat rentan dialami oleh lansia yang berada pada rentang usia diatas 60 tahun. Kondisi ini sering dijumpai pada lansia, baik laki-laki maupun perempuan, yaitu untuk lansia pada rentang usia diatas 65 tahun sebanyak $10 \%$ dan untuk lansia pada rentang usia diatas 85 tahun sebanyak 47\%. Kasus gangguan fungsi kognitif ini bersifat reversibel yang artinya dapat diobati dengan persentase sebanyak 10-20\%. Sekitar 5\% dari populasi lansia di Indonesia pada usia 65 tahun mengalami gangguan fungsi kognitif. Angka kejadian ini semakin meningkat pada lansia dengan rentang usia di atas yaitu sekitar 20\% (Amirullah dalam Guslinda dkk, 2013).

Gangguan kognitif adalah suatu gangguan yang erat kaitannya dengan penambahan usia manusia. Gangguan ini berdampak pada penurunan kemampuan otakdalam hal pemusatan perhatian, fokus, perhitungan, pengambilan keputusan, pemberian alas an atau logika dan berpikir abstrak (Shiang $\mathrm{Wu}, 2011$ dalam Wahyuniarti, 2012). Seiring dengan terjadinya proses menua pada manusia, maka terjadi pula penurunan kapasitas fungsional pada tingkat seluler dan tingkat organ (Kaplan, Sadock, \& Grebb, 2010). Gangguan kognitif salah satunya demensia atau pikun merupakan kumpulan gejala yang menghasilkan kehilangan kemampuan kognitif mencakup daya ingat tentang diri sendiri, orang lain, waktu, tempat dan aktivitas sehari- hari (Azizah, 2011). Gangguan fungsi kognitif yang terjadi pada lansia menimbulkan efek terhadap perubahan emosi dan tingkahlaku serta mengganggu lansia untuk melakukan aktifitas hariannya secara mandiri seperti aktifitas memenuhi gizi tubuh, aktifitas hygiene tubuh, dan lain-lain. Oleh karena itu diperlukan cara yang tepat untuk membantu lansia meningkatkan kemampuan kognitifnya melalui suatu intervensi perangsangan otak (Bandiyah, 2009).

Senam otak merupakan salah satu cara untuk meningkatkan stimulasi atau rangsangan pada otak manusia. Gerakan senam otak memberi manfaat untuk melatih otak sehingga dapat mengaktifkan kerja otak. Manusia yang suka mengaktifkan otaknya dalam berpikir akan membuat otaknya menjadi lebih sehat dibandingkan dengan orang yang tidak atau jarang menggunakan otaknya. Senam otak memiliki gerakan yang sangat praktis, dapat dilakukan oleh semua orang, dimana saja dan kapan saja (Septianti, 2016). Penelitian lain terkait pengaruh senam otak telah dilakukan sebelumnya oleh Guslinda dkk (2013) dengan hasil penelitian yang signifikan yaitu senam otak berpengaruh terhadap peningkatan fungsi kognitif lansia 
yang mengalami demensia. Hasil penelitian lainyang dilakukan oleh Agoes dkk (2016) juga menunjukkan hasil yang sama yaitu ada pengaruh terapi latihan otak (senam otak) terhadap peningkatan fungsi kognitif pada lansia.

Survey awal yang telah dilakukan peneliti di Balai Pelayanan dan Penyantunan Lanjut Usia (BPPLU) Pagar Dewa Provinsi Bengkulu didapatkan total lansia lakilaki dan perempuan adalah 60 orang yaitu 35 orang lansia laki-laki dan 25 orang perempuan. Hasil penilaian awal yang dilakukan oleh peneliti dengan menggunakan lembar kuesioner The Short Portable Mental Status Questionnaire (SPMSQ), dari 60 orang lansia tersebut didapatkan 35 orang lansia mengalami gangguan fungsi kognitif diantaranya 17 orang lansia laki-laki dan 18 orang lansia perempuan. Kondisi ini menyebabkan aktifitas harian yang biasa dilakukan lansia di BPPLU menjadi terganggu hingga berdampak pada perubahan tingkah laku lansia, seperti lebih sering berdiam diri di kamar atau di dalam wisma. Kondisi seperti ini tentunya dapat mempercepat terjadinya penurunan fungsi kognitif pada lansia di BPPLU tersebut, karena pada dasarnya lansia yang sering berdiam diri di kamar atau di dalam wisma ataupun tidak melakukan suatu aktivitas untuk mengasah kemampuan otaknya maka akan menyebabkan otak yang jarang diasah ini akan lebih cepat menjadi tidak aktif dalam berpikir.

Sepengetahuan peneliti, di BPPLU belum ada kegiatan rutin yang dilakukan untuk membantu meningkatkan fungsi kognitif pada lansia. Kegiatan yang dilakukan baru berupa Terapi Aktivitas Kelompok (TAK) yang sifatnya tidak rutin serta tidak spesifik utnuk membantu meningkatkan fungsi kognitif lansia. Kegiatan yang dilakukan lebih mengarah pada pemberian intervensi berupa penyuluhan kesehatan ataupun pemberian intervensi nonfarmakologi untuk mengurangi gejala penyakit degeneratif yang dialami oleh lansia. Untuk itulah peneliti ingin memberikan intervensi lainnya yaitu senam otak. Pemberian intervensi senam otak ini diharapkan dapat membantu lansia meningkatkan kemampuan fungsi kognitifnya, terutama bagi lansia yang telah mengalami penurunan fungsi kognitif baik pada lansia laki-laki maupun pada lansia perempuan, sedangkan bagi lansia yang belum mengalami penurunan kemampuan fungsi kognitif dengan kategori sedang atau berat, maka intervensi senam otak ini dapat dijadikan sebagai upaya pencegahan.

Berdasarkan latar belakang di atas, peneliti tertarik untuk meneliti perbedaan efektivitas senam otak terhadap peningkatan fungsi kognitif antara lansia laki-laki dan perempuan di Balai Pelayanan dan Penyantunan Lanjut Usia Pagar Dewa Provinsi Bengkulu. Adapun yang menjadi tujuan dari penelitian ini adalah untuk mengetahui perbedaan efektivitas peningkatan fungsi kognitif antara lansia laki-laki dan lansia perempuan sebelum dan setelah diberikan intervensi senam otak pada lansia yang mengalami gangguan fungsi kognitif. Hal ini didasari pada adanya teori yang menyatakan bahwa jenis kelamin merupakan salah satu faktor yang berpengaruh dalam penurunan dan peningkatan fungsi kognitif pada lansia.

\section{METODE PENELITIAN}

Penelitian ini merupakan penelitian kuantitatif dengan desain Eksperimen Semu (quasi experiment) with pre and posttest design. Rancangan penelitian jenis ini menggunakan dua kelompok sampel yang dibandingkan yaitu sampel lansia lakilaki dan lansia perempuan. Pengukuran dilakukan sebelum dan setelah perlakuan (Saryono, Anggraeni, 2013). 
Populasi dalam penelitian ini adalah lanjut usia laki-laki dan perempuan yang mengalami ganguan fungsi kognitif yang berjumlah 35 orang. Penelitian ini menggunakan tehnik total sampling dan metode consecutive sampling. Sampel akhir yang didapatkan adalah 15 orang sampel lansia laki-laki dengan klasifikasi gangguan kognitif sedang 11 orang, gangguan kognitif berat 4 orang, dan 15 sampel lansia perempuan dengan gangguan kognitif sedang 11 orang, gangguan kognitif berat 4 orang. Lansia diberikan terapi senam otak 3 kali dalam satu minggu berjarak 1 hari perminggu selama 2 minggu, yang kemudian diukur kembali tingkat gangguan kognitif responden setelah 2 minggu melakukan senam otak dengan menggunakan kuesioner SPMSQ.

Sebelum data dianalisis dilakukan uji normalitas terlebih dahulu untuk mengetahui apakah data yang didapat dari hasil penelitian tersebut berdistribusi normal. Metode untuk mengetahui data berdistibusi normal atau tidak adalah dengan menggunakan nilai skewnes dan standar error, bila nilai sweeknes dibagi standar error menghasilkan angka $<2$, maka distribusinya normal (Dahlan, 2011). Hasil uji normalitas yang dilakukan didapatkan data berdistribusi normal, sehingga uji analisis yang digunakan pada data hasil penelitian ini adalah uji t independen.

\section{HASIL PENELITIAN Analisis Univariat}

Tabel. 1

Distribusi Frekuensi Fungsi Kognitif Sebelum Diberikan Intervensi Senam Otak pada Lansia Laki-Laki

\begin{tabular}{|c|c|c|}
\hline $\begin{array}{c}\text { Fungsi } \\
\text { Kognitif }\end{array}$ & Frekuensi & $\begin{array}{c}\text { Persentasi } \\
(\%)\end{array}$ \\
\hline Normal & 0 & 0 \\
\hline $\begin{array}{l}\text { G.kognitif } \\
\text { Ringan }\end{array}$ & 0 & 0 \\
\hline $\begin{array}{l}\text { G.kognitif } \\
\text { Sedang }\end{array}$ & 11 & 73,3 \\
\hline $\begin{array}{l}\text { G.kognitif } \\
\text { Berat }\end{array}$ & 4 & 26,7 \\
\hline Total & 15 & 100 \\
\hline
\end{tabular}

Berdasarkan tabel 1 di atas dengan jumlah sampel 15 orang lansia laki- laki didapatkan bahwa mayoritas tertinggi skor gangguan fungsi kognitif sebelum melakukan senam otak yaitu gangguan fungsi kognitif sedang sebanyak 11 orang $(73,3 \%)$, dan gangguan fungsi kognitif berat sebanyak 4 orang $(26,7 \%)$.

Tabel. 2

Distribusi Frekuensi Fungsi Kognitif Sebelum Diberikan Intervensi Senam Otak pada Lansia Perempuan

\begin{tabular}{lcc}
\hline $\begin{array}{c}\text { Fungsi } \\
\text { Kognitif (pre test) }\end{array}$ & Frekuensi & $\begin{array}{c}\text { Persentasi } \\
(\%)\end{array}$ \\
\hline Normal & 0 & 0 \\
G.kognitif & 0 & 0 \\
Ringan & & \\
\hline
\end{tabular}




\begin{tabular}{lcc}
\hline G.kognitif & 11 & 73,3 \\
Sedang & & \\
$\begin{array}{l}\text { G.kognitif } \\
\text { Berat }\end{array}$ & 4 & 26,7 \\
$\mid$ Total & 15 & 100 \\
\hline
\end{tabular}

Berdasarkan tabel 2 di atas dengan jumlah sampel 15 orang lansia perempuan didapatkan bahwa mayoritas tertinggi skor gangguan fungsi kognitif sebelum melakukan senam otak yaitu gangguan fungsi kognitif sedang sebanyak 11 orang $(73,3 \%)$, dan gangguan fungsi kognitif berat sebanyak 4 orang $(26,7 \%)$.

Tabel. 3

Distribusi Frekuensi Fungsi Kognitif Sesudah Diberikan Intervensi Senam Otak pada Lansia Laki-Laki

\begin{tabular}{lcc}
\hline \multicolumn{1}{c}{ Fungsi } & Frekuensi & $\begin{array}{c}\text { Persentasi } \\
(\%)\end{array}$ \\
\hline Normal & 0 & 0 \\
G.kognitif & 10 & 66,7 \\
Ringan & & \\
$\begin{array}{l}\text { G.kognitif } \\
\text { Sedang }\end{array}$ & 5 & 33,3 \\
$\begin{array}{l}\text { G.kognitif } \\
\text { Berat }\end{array}$ & 0 & 0 \\
Total & 15 & 100 \\
\hline
\end{tabular}

Berdasarkan tabel 3 di atas dengan jumlah sampel 15 orang lansia laki- laki didapatkan bahwa mayoritas tertinggi skor gangguan fungsi kognitif sesudah melakukan senam otak yaitu gangguan fungsi kognitif ringan sebanyak 10 orang $(66,7 \%)$, dan gangguan fungsi kognitif sedang sebanyak 5 orang $(33,3 \%)$.

Tabel. 4

Distribusi Frekuensi Fungsi Kognitif Sesudah Diberikan Intervensi Senam Otak pada Lansia Perempuan

\begin{tabular}{lcc}
\hline \multicolumn{1}{c}{ Fungsi } & Frekuensi & $\begin{array}{c}\text { Persentasi } \\
(\%)\end{array}$ \\
Kognitif (post test) & 0 & 0 \\
Normal & 5 & 33,3 \\
G.kognitif & & \\
Ringan & & 53,3 \\
G.kognitif & 8 & 13,3 \\
$\begin{array}{l}\text { Sedang } \\
\text { G.kognitif } \\
\text { Berat } \\
\text { Total }\end{array}$ & 2 & 100 \\
\hline
\end{tabular}

Berdasarkan tabel 4 di atas dengan jumlah sampel 15 orang lansia perempuan didapatkan bahwa mayoritas tertinggi skor gangguan fungsi kognitif sesudah melakukan senam otak yaitu gangguan fungsi kognitif ringan sebanyak 5 orang $(33,3 \%)$, gangguan fungsi kognitif sedang sebanyak 8 orang $(53,3 \%)$, dan gangguan 
fungsi kognitif berat sebanyak 2 orang $(13,3 \%)$.

\section{Analisis Bivariat}

Tabel. 5

Distribusi Rata-Rata Perbedaan Efektifitas Fungsi Kognitif Antara Lansia Laki-Laki dan Perempuan

\begin{tabular}{cccccc}
\hline Fungsi Kognitif & Mean & SD & SE & P Value & $\mathrm{n}$ \\
\hline $\begin{array}{c}\text { Post test lansia Laki- } \\
\text { Laki }\end{array}$ & 4,00 & 1,000 & 0,258 & & \\
$\begin{array}{c}\text { Post test lansia } \\
\text { Perempuan }\end{array}$ & 5,20 & 1,656 & 0,428 & 0,025 & 15 \\
\hline
\end{tabular}

Berdasarkan tabel 5 di atas dengan jumlah sampel 15 orang lansia laki- laki dan 15 orang lansia perempuan diketahui rata-rata skor gangguan fungsi kognitif sesudah diberikan senam otak pada lansia laki-laki adalah 4,00, sedangkan pada lansia perempuan adalah 5,20 sehingga ada perbedaan efektivitas fungsi kognitif sesudah diberikan senam otak antara lansia laki-laki dan perempuan di Balai Pelayanan dan Penyantunan Lanjut Usia Pagar Dewa Provinsi Bengkulu, yang menunjukan laki- laki lebih efektif dari pada perempuan, dimana semakin kecil ratarata skor gangguan fungsi kognitif maka semakin besar peningkatan fungsi kognitifnya. Hasil uji $\mathrm{T}$ independen didapat $\mathrm{P}$ value 0,025 . Hasil ini memberikan interpretasi bahwa terdapat perbedaan efektivitas senam otak terhadap peningkatan fungsi kognitif antara lansia laki-laki dan perempuan di Balai Pelayanan dan Penyantunan Lanjut Usia Pagar Dewa Provinsi Bengkulu.

\section{PEMBAHASAN}

\section{Analisis Univariat}

\section{Skor Gangguan Fungsi Kognitif Sebelum Diberikan Senam Otak Antara Lansia Laki-Laki dan Perempuan}

Berdasarkan hasil penelitian menunjukkan bahwa dari 15 responden lansia laki-laki sebagian besar responden mengalami gangguan fungsi kognitif sedang sebanyak 11 orang $(73,3 \%)$, dan gangguan fungsi kognitif berat sebanyak 4 orang $(26,7 \%)$ dan dari 15 responden lansia perempuan sebagian besar responden mengalami gangguan fungsi kognitif sedang sebanyak 11 orang $(73,3 \%)$, dan gangguan fungsi kognitif berat sebanyak 4 orang $(26,7 \%)$. Hasil penelitian ini menunjukkan bahwa terdapat kesamaan jumlah responden yang mengalami gangguan kognitif sedang dan juga berat baik pada lansia laki-laki maupun pada lansia perempuan sebelum pemberian intervensi senam otak.

Hasil penelitian ini berbeda dengan teori Myers dalam Agoes (2016) yang menyatakan bahwa jenis kelamin wanita lebih berisiko untuk mengalami gangguan atau penurunan fungsi kognitif dibandingkan jenis kelamin laki-laki. Kondisi ini dikaitkan dengan adanya peranan level hormon seks endogen dalam perubahan fungsi kognitif. Selain itu, adanya reseptor estrogen seperti hipokampus dalam area otak memiliki peran dalam fungsi belajar dan memori. Menurut teori level estradiol dalam tubuh manusia berhubungan dengan fungsi kognitif. Level estradiol yang rendah di dalam tubuh berkaitan dengan penurunan fungsi kognitif dan memori verbal pada manusia. Estradiol diperkirakan memiliki sifat neuroprotektif yaitu dapat membatasi kerusakan akibat stres oksidatif serta melindung sel saraf penderita 
Alzheimer dari toksisitas amiloid.

Menurut Rosita (2012) gangguan kesehatan yang dapat muncul pada usia lanjutadalah gangguan mental. Depresi dan gangguan fungsi kognitif merupakan contoh gangguan mental yang sering muncul pada lansia.Faktor lain yang menyebabkan gangguan fungsi kognitif pada lansia adalah faktor resiko psikososial, seperti hilangnya peranan sosial, hilangnya ekonomi, kematian teman atau sanak saudaranya, penurunan kesehatan, peningkatan isolasi karena hilangnya interaksi sosial dan penurunan fungsi kognitif. Penurunan fungsi kognitif ini akan menimbulkan pergeseran bagi lansia khususnya peranan dalam berinteraksi sosial dengan keluarga ataupun masyarakat sehingga menyebabkan lansia merasa diasingkan dan tidak berguna (Stanley, Bare, 2007). Kondisi yang dialami lansia ini berpeluang untuk mengakibatkan masalah kesehatan pada kondisi fisik maupun masalah kesehatan jiwa (Nugroho, 2012).

Adanya kesulitan mengingat yang terjadi pada usia lanjut perlu untuk dilakukan pemeriksaan atau anamnesa. Pemeriksaan atau anamnesa pada fungsi kognitif diusia lanjut bertujuan untuk membantu mengidentifikasi lansia yang berisiko mengalami penurunan fungsi kognitif, sehingga dapat dilakukan pencegahan secara dini (Gallo, Reichel \& Andersen, 2000). Perkembangan kognitif di usia lanjut pada umumnya terdiri dari tiga perkembangan yaitu perkembangan pemikiran postformal, perkembangan memori, dan perkembangan intelegensi, dimana ketiganya ini akan mengalami kemunduran seiring dengan bertambahnya usia lansia (Desmita, 2010). Perkembangan pemikiran postformal ditandai dengan cara berpikir yang reflektif, realistis, pragmatis, dan bervariasi dalam menyelesaikan berbagai permasalahan (Izzaty, Yulia, 2015). Menurut Suparmi (2010) memori merupakan sistem penyimpanan atau ingatan dancara untuk mempelajari hal-hal baru. Kemampuan mengingat yang baik akan membuat seseorang mendapatkan sumber-sumber informasi yang banyak, namun pada lansia kemampuan memori ini akan menurun seiring bertambahnya usia. Perkembangan intelegensi pada lansiamengalami kemunduran khususnya dalam intelegensi umum seiring dengan proses penuaan.

Menurut Azizah (2011) salah satu gangguan kognitif pada lansia adalah demensia atau pikun, yaitu kumpulan gejala yang menghasilkan kehilangan kemampuan kognitif mencakup daya ingat tentang diri sendiri, orang lain, waktu, tempat, dan aktivitas sehari-hari. Perubahan kognitif pada lansia jugaterjadi pada perubahan daya ingat (memori), IQ (Intelegent Quocient), kemampuan memaknai suatu hal, mencari solusi dari suatu permasalahan, mengambil keputusan, bijaksana dalam bersikap, dan kinerja. Gangguan kognitif yang dialami lansia akan menyebabkan lansia tidak bisa mengerjakan semua aktifitas hariannya dengan mandiri. Lansia membutuhkan bantuan dari orang lain sehingga aktifitas lansia menjadi tergantung pada orang lain. Lansia yang sudah jarang mengasah kemampuan otak dan pikirannya akan berpeluang lebih besar mengalami kemunduran atau penurunan fungsi kognitif. Oleh karena itu diperlukan suatu metode yang dapat digunakan untuk meningkatkan kemampuan fungsi kogntif lansia (Bandiyah, 2009).

Pada hasil penelitian ini, perubahan kognitif pada lansia berupa penurunan fungsi kognitif terjadi pada perubahan daya ingat dan kinerja. Hal ini terlihat dari hasil pengukuran dengan wawancara yang berdasarkan pada panduan kuesioner SPMSQ yaitu sebagian responden tidak dapat mengingat (lupa) tanggal, bulan, 
usianya, dan kapan responden dilahirkan. Responden hanya mencoba untuk memperkirakan usia dan tahun kelahirannya. Ditinjau dari aspek kinerja, sebagian besar responden di BPPLU mengalami penurunan kinerja. Hal ini dapat dilihat dari aktivitas keseharian lansia yang hanya menghabiskan atau mengisi waktu luang dengan berdiam di kamarnya masing-masing, duduk-duduk di dalam wisma dan teras wisma tanpa melakukan kegiatan atau aktifitas yang berarti terutama aktifitas yang terkait untuk peningkatan fungsi kognitif atau peningkatan kesehatan lainnya. Hal ini dipicu karena kurangnya interaksi sosial diantara sesama lansia. Namun, sesekali lansia saling berinteraksi dengan teman satu wismanya untuk waktu yang tidak lama.

Stanley (2006) menyatakan bahwa seseorang yang berada pada usia 80 tahun akan mengalami perubahan dalam sistem neurologisnya yaitu penyusutan neuron, dengan potensial $10 \%$ kehilangan yang diketahui. Oak yang terdapat dalam sistem neurologis terutama otak merupakan faktor utama dalam penuaan yang adaptif. Adanya sel-sel neuron pada otak bertugas untuk menyalurkan impuls listrik dari susunan saraf pusat. Seiring dewasanya usia seseorang, maka sel-sel neuron terus tumbuh dan menjadi semakin kompleks, namun neuron tersebut tidak dapat mengalami regenerasi atau pembaharuan. Pada usia lanjut otak kehilangan 100.000 neuron pertahun. Berat otak pada manusia adalah $2 \%$ dari berat badan, namun mengkonsumsi $20 \%$ dari total kebutuhan konsumsi oksigen. Aliran darah serebral pada orang dewasa kurang lebih $50 \mathrm{cc} / 100 \mathrm{gm} / \mathrm{menit}$, dan pada usia lanjut menurun menjadi $30 \mathrm{cc} / 100 \mathrm{gm} /$ menit. Penurunan berat otak pada manusia terjadi pada usia 45-50 tahun yaitu sekitar11\% dari berat maksimal. Penelitian pada otak menunjukkan bahwa walaupun neuron mengalami kematian, terjadi peningkatan hubungan di antara sel yang tersisa dan mengisi kekosongan yang ada. Kondisi ini secara perlahan mendukung kemampuan tugas kognitif lansia seperti yang telah dilakukannya pada beberapa tahun sebelumnya. Otak mengalami perubahan struktural dan menimbulkan pengaruh pada bagian lain dari sistem saraf pusat (SSP). Terjadinya perubahan ukuran otak disebabkan oleh pengecilan girus dan pelebaran sulkus serta ventrikel otak. Semakin bertambahnya usia seseorang struktur dan fungsi pada sistem saraf akan mengalami perubahan. Berkurangnya massa otak progresif diakibatkan oleh berkurangnya sel saraf yang tidak bisa digantikan (Smeltzer, 2001).

Denney dalam Yusuf (2010) mengungkapkan bahwa kebanyakan tes kemampuan mengingat dan memecahkan masalah mengukur bagaimana orang dewasa lanjut melakukan aktivitas yang abstrak atau sederhana. Gangguan pada sistem transmisi (neurotransmitter) sel-sel saraf pusat otak manusia dapat berdampak terjadinya gangguan mental dan perilaku (mental and behaviour disorder), salah satu akibatnya adalah melemahnya fungsi kognitif khususnya kemampuan untuk menemukan solusi dari suatu permasalahan, ingatan, atensi dan bahasa. Pada umumnya kenangan untuk kejadian masa lalu lebih banyak tertahan dan diingat dibandingkan informasi yang bersifat masih baru. Kondisi ini disebut dengan istilah deprivasi sensori yang disebabkan karena adanya kerusakan pada pusat cerebral yang bertanggung jawab untuk memproses rangsangan. Tingkat kerusakan cerebral akan menentukan apakah penurunan ini bersifat progresif, permanen atau temporer. Deprivasi sensori kemungkinan disebabkan oleh halusinasi, disorientasi, dan konfusi (Smeltzer, 2001). 


\section{Skor Gangguan Fungsi Kognitif Sesudah Diberikan Senam Otak Antara Lansia Laki-Laki dan Perempuan}

Berdasarkan hasil penelitian dapat dilihat bahwa setelah diberikan senam otak dari 15 responden lansia laki- laki sebagian besar respondenmengalami gangguan fungsi kognitif ringan sebanyak 10 orang $(66,7 \%)$, dan gangguan fungsi kognitif sedang sebanyak 5 orang $(33,3 \%)$ dan dari 15 responden lansia perempuan sebagian besar responden mengalami gangguan fungsi kognitif sedang sebanyak 8 orang $(53,3 \%)$, gangguan fungsi kognitif ringan sebanyak 5 orang $(33,3 \%)$, dan gangguan fungsi kognitif berat sebanyak 2 orang $(13,3 \%)$.

Menurut hasil penelitian Maryati dkk (2013) terjadinya perubahan fungsi kognitif pada seseorang dikarenakan adanyafaktor predisposisi yang biasanya terjadi karena adanya gangguan biologis pada fungsi sistem saraf pusat. Gangguan biologis tersebut seperti gangguan suplai oksigen ke otak, degenerasi yang berhubungan dengan penuaan, pengumpulan zat beracun dalam jaringan otak, penyakit Alzheimer, virusimunodefisiensi manusia (HIV), penyakit hati kronik, penyakit ginjal kronik, defisiensi vitamin (terutama tiamin), malnutrisi, abnormalitas genetik dan gangguan jiwa mayor. Hipoksia, gangguan metabolik, toksisitas dan infeksi, respons yang berlawanan terhadap pengobatan, perubahan struktur otak, seperti tumor atau trauma dan kekurangan atau kelebihan sensori merupakan faktor pencetus lain gangguan fungsi kognitif. Adanya perubahan struktur dan fungsi otak pada proses menua berhubungan dengan terjadinya penurunan dalam hal kecepatan, memori jangka pendek dan jangka panjang, serta memori kerja (Raz, Rodrigue, 2006 dalam Pascana, 2011).

The U.S Departement of Health and Human Services (2011) merilis faktor risiko lain yang berpengaruh terhadap penurunan fungsi kognitif yaitu keturunan, jenjang pendidikan, cedera otak, racun, tidak melakukan aktivitas fisik, dan penyakit kronik seperti parkinson, jantung, stroke serta diabetes mellitus. Sebagian besar lansia justru mengurangi aktifitas fisiknya dengan berbagai alasan seperti merasa bahwa aktifitas fisik olahraga tidak cocok dilakukan di usia lanjut, atau lansia mengatakan bahwa mereka telah mengalami penurunan kesehatan sehingga tidak bisa lagi melakukan aktivitas fisik atau olahraga (Lee, Arthur \& Avis, 2008; Baert, dkk, 2011).

Fungsi kognitif juga dipengaruhi oleh faktor, salah satunya adalah usia. Seiring dengan bertambahnya usia pada manusia, maka akan terjadi penurunan fungsi kognitif. Penurunan fungsi kognitif pada lansia merupakan salah satu penyebab meningkatnya ketergantungan lansia dalam melakukan aktivitas seharihari. Gangguan fungsi kognitif merupakan respon maladaptif yang ditandai oleh terganggunya daya ingat, disorientasi, inkoheren, dan sukar berpikir logis. Muzamil dkk (2014) menyatakan faktor-faktor gaya hidup seperti stimulasi intelektual, status sosial dan aktivitas fisik dapat menurunkan resiko untuk terjadinya gangguan yang berhubungan dengan usia. Aktifitas fisik diduga dapat menstimulasi pertumbuhan saraf yang kemungkinan dapat menghambat penurunan fungsi kognitif pada lansia. Aktivitas fisikyang banyak dilakukan lansia merupakan salah satu contoh tindakan pencegahan penurunan fungsi kognitif (Blondell, Hammersley-Mather \& Veerman (2014) dalam Sauliyusta, Etty, 2016).

Aktivitas fisik yang dapat dilakukan pada usia lanjut seperti salah satunya olahraga ringan yaitu dengan gerakan senam otak. Senam otak merupakan gerakan senam sederhana yang menggunakan keseluruhan otak, bersifat menyenangkan dan 
bermanfaat untuk meningkatkan kemampuan belajar (Septianti, 2016). Senam otak dapat menghasilkan rangsangan yang dapat meningkatkan kemampuan kognitif yaitu kewaspadaan, konsentrasi, kecepatan, persepsi, belajar, memori (Nugroho dalam Yuliniarsi, 2014). Senam otak dapat dilakukan oleh siapa saja, termasuk lansia. Penurunan kemampuan otak yang umumnya dialami lansia dapat diperbaiki dengan senam otak. Hal ini dikarenakan senam otak akan memperlancar aliran darah dan oksigen ke otak. Selain itu, gerakan- gerakan yang ada pada senam otak bisa merangsang kerja dan berfungsinya otak secara optimal. Senam otak dapat mengaktifkan kemampuan otak kanan dan kiri, sehingga kerjasama antara belahan otak kanan dan kiri dapat tercipta (Dennison, 2003). Gerakan-gerakan sederhana pada senam otak bertujuan untuk menghubungkan atau menyatukan akal dan tubuh. Hal ini dikarenakan proses belajar, berpikir, kreatifitas dan kecerdasan tidak hanya melibatkan otak melainkan juga seluruh tubuh. Sensasi, gerakan, emosi dan fungsi integrasi otak semua bersumber pada tubuh (Sularyo, Setyo, 2002).

\section{Analisis Bivariat \\ Perbedaan Efektivitas Senam Otak terhadap Peningkatan Fungsi Kognitif antara Lansia Laki-Laki dan Perempuan}

Berdasarkan hasil penelitian diketahui bahwa sebagian besar sampel penelitian menyatakan bahwa setelah melakukan intervensi senam otak, lansia merasakan adanya manfaat serta ada perbedaan efektifitas peningkatan fungsi kognitif. Hasil peningkatan fungsi kognitif ini berbeda antara lansia laki-laki dan lansia perempuan, dimana didapatkan hasil bahwa peningkatan fungsi kognitif pada lansia laki-laki lebih besar dibandingkan peningkatan fungsi kognitif pada lansia perempuan. Dengan kata lain pemberian intervensi senam otak lebih efektif pada lansia laki-laki dibandingkan pada lansia perempuan.

Hasil penelitian ini sejalan dengan pendapat Purwanto (2009) bahwa dengan melakukan senam otak, banyak efek atau manfaat yang bisa diperoleh. Senam otak bertujuan untuk melatih mengaktifkan kerja otak. Hal ini dikarenakan latihan pada senam otak merupakan educational kinestology yang berarti ilmu tentang gerakan tubuh manusia (Septianti, 2016). Metode latihan educational kinestology ini mengakifkan kerja seluruh otak dengan menggunakan pembaruan pola gerakan tertentu untuk membuka bagian-bagian otak yang sebelumnya tertutup atau terhambat (Anggriyana, Atikah, 2010).

Gerakan-gerakan olah tangan dan kaki yang sederhana dalam gerakan senam otak dapat memberikan efek berupa rangsangan atau stimulus pada otak. Stimulus yang muncul pada otak akan meningkatkan kemampuan kognitif, menyelaraskan kemampuan beraktivitas dan berfikir pada saat yang bersamaan, menyeimbangkan kontrol emosi dan logika, fungsi kinerja panca indera dimaksimalkan, menjaga kelenturan dan keseimbangan tubuh, meningkatkan ketajaman ingatan dan pengulangan kembali terhadap huruf atau angka, meningkatkan ketajaman dalam pendengaran dan penglihatan, meminimalisir kesalahan membaca dan mengingat, sertsa dapat meningkatkan respon terhadap rangsangan visual. Anggriyana dan Atikah (2010) menambahkan bahwa senam otak dapat melancarkan aliran darah dan oksigen ke otak, meningkatkan daya ingat dan konsentrasi serta meningkatkan energi tubuh.

Hasil analisis statistik terhadap perbedaan efektivitas peningkatan fungsi kognitif antara lansia laki-laki dan perempuan menunjukkan nilai $p$ value $=0,025$. 
Karena nilai $\mathrm{p}$ value $<0,05$ (95\% kepercayaan), artinya bahwa ada perbedaan efektivitas senam otak terhadap peningkatan fungsi kognitif antara lansia laki-laki dan perempuan di Balai Pelayanan dan Penyantunan Lanjut Usia Pagar Dewa Provinsi Bengkulu. Hasil penelitian ini juga menunjukkan bahwa senam otak lebih efektif untuk meningkatkan fungsi kognitif pada lansia laki-laki dibandingkan dengan lansia perempuan.

Adanya perbedaan peningkatan fungsi kognitif antara lansia laki-laki dan lansia perempuan pada hasil penelitian ini, dimana peningkatan fungsi kognitif pada lansia wanita lebih kecil dibandingkan pada lansia laki-lakisesuai dengan teori Myers dalam Agoes dkk, (2016) bahwa wanita lebih beresiko mengalami penurunan kognitif dari pada laki-laki. Hal ini dikaitkan dengan rendahnya level hormon seks endogen dan level estradiol dalam tubuh.

Menurut peneliti perbedaan peningkatan fungsi kognitif yang terjadi antara lansia laki-laki dan lansia perempuan salah satunya dipengaruhi oleh tingkat keseriusan lansia dalam mengikuti intervensi senam otak yang diberikan. Lansia laki-laki lebih serius dan memiliki motivasi yang tinggi dalam mengikuti setiap gerakan pada senam otak disertai dengan gerakan yang sesuai dengan yang telah diajarkan, sedangkan lansia perempuan tidak terlalu serius atau kurang termotivasi, lansia perempuan hanya sekedar menggerakkan jari-jarinya, dan kadang-kadang terlambat dalam mengikuti gerakan, bahkan didapatkan ada lansia perempuan yang berhenti sejenak mengikuti gerakan senam otak dan kemudian melanjutkannya kembali. Hal ini disebabkan lansia perempuan merasa sedikit malu dan kurang percaya diri untuk melakukan gerakan senam otak, padahal gerakan dalam senam otak ini merupakan gerakan yang sederhana.

Menurut penelitian Frederikse (2000) dalam Wardana dan Kemil (2017) mengenai adanya perbedaan lobusparietal antara jenis kelamin laki- laki dan perempuan yang dibuktikan bahwa inferior parietalotak sebelah kiri lebih besar pada laki-laki dari pada perempuan. Bagian lobus parietal tersebut sangat berfungsi dalam menyelesaikan tugas-tugas kognitif, terutama yang berhubungan dengan persepsi, dan proses visuospasial. Jadi kondisi inilah yang mendukung terjadinya peningkatan fungsi kognitif pada lansia laki-laki yang mengalami penurunan fungsi kognitif lebih efektif dibandingkan pada lansia perempuan setelah diberikan intervensi senam otak selama 2 minggu dengan frekuensi 3x dalam seminggu dan dengan durasi waktu selama 30 menit untuk 1 kali sesi latihan.

Hasil penelitian ini diperkuat dengan hasil penelitian Guslinda dkk (2013) yang melakukan penelitian tentang pengaruh senam otak terhadap fungsi kognitif pada lansia dengan demensia di Panti Sosial Tresna Werdha Sabai Nan Aluih Sicincin Padang Pariaman tahun 2013, didapatkan nilai $p$-Value $=0,000$ yang berarti bahwa terdapat perbedaan yang signifikan antara peningkatan fungsi kognitif antara sebelum dan sesudah dilakukan senam otak. Hal ini dikarenakan intervensi gerakan senam otak yang diberikan, dilakukan secara benar dan teratur selama 2 minggu dengan frekuensi 2 kali dalam seminggu. Selain itu, secara teori diketahui bahwa stimulus dari gerakan senam otak yang sudah dilakukan dapat merangsang kedua belahan otak untuk bekerja atau lebih aktif lagi. Senam otak bertujuan untuk mengaktifkan kembali pusat-pusat reticulo activating system pada batang otak sehingga dapat menstimulasi otak agar memiliki kesadaran dan daya intelektual yang kuat. Faktor pendukung lainnya adalah karena sebagian besar responden $(58,3 \%)$ mengalami demensia ringan dengan jumlah skor fungsi kognitif yang 
mendekati normal sehingga setelah melakukan gerakan senam otak secara rutin selama 2 minggu terjadi peningkatan fungsi kognitif menjadi normal.

Hasil penelitian Setiawan dkk (2014) juga sesuai dengan penelitian ini, yang melakukan penelitian tentang pengaruh senam otak terhadap fungsi kognitif lansia demensia di Panti Wredha Darma Bakti Kasih Surakarta, dengan hasil ada pengaruh senam otak dengan fungsi kognitif lansia yang mengalami demensia.Hal ini dikarenakan terapi senam otak diberikan dengan kuantitas yang banyak, yaitu setiap hari selama 2 kali dengan durasi waktu 15 menit secara teratur selama 3 minggu. Hasil penelitian ini juga sesuai dengan penelitian yang dilakukan oleh Agoes dkk (2016) tentang pengaruh terapi latihan otak (senam otak) terhadap peningkatan fungsi kognitif pada lansia, dengan hasil ada pengaruh terapi latihan otak (senam otak) terhadap peningkatan fungsi kognitif pada lansia. Hal ini dikarenakan terapi senam otak diberikan setiap hari yaitu 2 kali dalam sehari secara teratur selama 3 minggu dengan durasi 15 menit. Pelaksanaan senam otak dengan frekuensi 2 kali dalam sehari secara teratur selama 3 minggu dengan durasi 15 menit ini dapat mengurangi terjadinya penurunan fungsi kognitif. Hal ini dikarenakan prinsip dari senam otak ini adalah mengaktifkasn otak ke dalam tiga fungsi yaitu dimensi silateralis (otak kiri-kanan), dimensi pemfokusan (otak depan-belakang), dan dimensi pemusatan (otak atas-bawah), masing-masing dimensi ini memiliki tugas tertentu (Denisson, 2009).

Menurut analisa peneliti, hasil penelitian yang menunjukkan bahwa fungsi kognitif lansia laki- laki lebih efektif dari pada lansia perempuan setelah melakukan senam otak, dikarenakan pada saat pelaksanaan intervensi lansia laki-laki lebih bersemangat mengikuti senam dari awal hingga akhir dibandingkan dengan lansia perempuan di setiap pelaksanaan intervensi senam otak ini. Hasil observasi dari pergerakan senam seperti gerakan tangan, lansia laki-laki dapat mengikutinya dengan baik dibandingkan dengan lansia perempuan atau dengan kata lain lansia laki-laki memiliki motivasi yang lebih tinggi dalam mengikuti intervensi senam otak yang diberikan. Gerakan senam yang dilakukan dengan baik sesuai dengan SOP (Standar Operasional Prosedure) yang diajarkan akan memberikan manfaat atau hasil yang lebih baik juga bagi pelakunya.

\section{SIMPULAN}

Terdapat peningkatan fungsi kognitif baik pada lansia laki-laki maupun lansia perempuan setelah diberikan intervensi senam otak. Ada perbedaan efektivitas senam otak terhadap peningkatan fungsi kognitif antara lansia laki-laki dan lansia perempuan di Balai Pelayanan Penyantunan Lanjut Usia Pagar Dewa Provinsi Bengkulu, dimana fungsi kognitif lansia laki-laki lebih meningkat dibandingkan lansia perempuan setelah diberikan intervensi senam otak selama 2 minggu dengan frekuensi 3x seminggu dan durasi waktu 30 menit di setiap sesinya.

Dengan kata lain senam otak lebih efektif pada lansia laki-laki untuk meningkatkan fungsi kognitifnya. Hasil penelitian ini dapat memberikan informasi ilmiah yang bermanfaat bagi mahasiswa khususnya mahasiswa keperawatan yang nantinya akan memberikan pelayanan kepada masyarakat secara langsung, terutama pada lansia baik di pelayanan kesehatan primer atau puskesmas, rumah sakit, panti sosial atau tresna werda, maupun di komunitas. 


\section{SARAN}

Disarankan kepada petugas panti terutama perawat yang ada di Balai Pelayanan dan Penyantunan Lanjut Usia (BPPLU) Pagar Dewa Provinsi Bengkulu untuk melakukan upaya peningkatan kesehatan pada lansia terutama melakukan senam otak untuk mencegah penurunan fungsi kognitif pada lansia dan bagi lansia yang mengalami gangguan fungsi kognitif untuk dapat meningkatkan fungsi kognitifnya sehingga mencegah terjadinya gangguan fungsi kognitif yang lebih parah.

Hasil penelitian ini dapat dijadikan referensi untuk penelitian lebih lanjut yang berkaitan dengan intervensi senam otak pada pasien yang mengalami gangguan fungsi kognitif atau meneliti faktor-faktor lain yang dapat meningkatkan fungsi kognitif pada lansia yang mengalami gangguan atau penurunan dengan menambah variable-variabel penelitian lain, atau dengan cara mengkombinasikan intervensi senam otak ini dengan pendekatan lainnya yang sesuai. Penelitian lanjutan juga dapat dilakukan dengan jumlah responden yang lebih banyak dan kriteria responden yang lebih spesifik, waktu dan frekuensi intervensi yang lebih panjang, serta dengan desain metode penelitian lain, seperti menggunakan kelompok kontrol atau yang lainnya.

\section{DAFTAR PUSTAKA}

Agoes. (2016). Pengaruh Terapi Latihan Otak (Brain Age) terhadap Peningkatan Fungsi Kognitif pada Lansia. MNJ, 2(2). Juli 2016

Anggriyana \& Atikah. (2010). Senam Kesehatan. Yogyakarta: Nuha Medika

Azizah. (2011). Keperawatan Lanjut Usia. Yogyakarta : Graha Ilmu

Baert, V., Gorus, E., Mets, T., Geerts, C., \& Bautmans, I. (2011). Motivators and Barriers for Physical Activity in Older Old: A Systematic Review. Ageing Research, 10.464-476.doi: 10.1016/j.arr.2011.04.001, diakses dari http:// www.ncbi.nlm.nih.gov/pubmed/21570493, pada tanggal 3 Februari 2018

Bandiyah, S. (2009). Lanjut Usia dan Keperawatan Gerontik. Yogyakarta: Nuha Medika

Dahlan, S. 2011. Statistik Untuk Kedokteran dan Kesehatan. Jakarta: Salemba Medika

Dennison, P., Gail, E. (2003). Buku Panduan Lengkap Brain Gym. Jakarta: Gramedia

Desmita. (2010). Psikologi Perkembangan. Bandung : Remaja Rosdakarya

Gallo, J.J., Reichel, W. \& Andersen, L.M. (2000). Buku Saku Gerontologi, edisi 2. Jakarta: Penerbit Buku Kedokteran EGC

Guslinda. (2013). Pengaruh Senam Otak terhadap Fungsi Kognitif pada Lansia dengan Demensia di Panti Sosial Tresna Werdha Sabai Nan Aluih Sicincin Padang Pariaman Tahun 2013

Izzaty, R. E \& Yulia, A. (2015). Psikologi Perkembangan Dewasa dan Lansia : Perkembangan Fisik dan Kognitif Masa Dewasa Awal. Universitas Negeri Yogyakarta

Kaplan, H.I, Sadock, B. J, Grebb, J. A. (2010). Sinopsis Psikiatri Jilid 2. Terjemahan Widjaja Kusuma. Jakarta: Binarupa Aksara

Kementerian Kesehatan Republik Indonesia. (2013). Populasi Lansia Diperkirakan Terus Meningkat Hingga Tahun 2020. Diakses dari http://www.depkes.go.id, pada tanggal 28 Januari 2018 
Lee, L.L., Arthur, A., \& Avis, M. (2008). Using Self-Efficacy Theory to Develop Interventions that Help Older Oepole Overcome Psychological Barriers to Physical Activity: A Discussion Paper. International Journal of Nursing Studies, 45, 1690-1699. doi: http://dx.doi.org/ 10.1016/j.ijnurstu.2008.02.012. diakses dari http://www.ncbi.nlm.nih.gov/pubmed/18501359, pada tanggal 28 Januari 2018

Maryam, R. S. (2011). Mengenal Usia Lanjut dan Perawatannya. Jakarta : Salemba Medika

Maryati. (2013). Gambaran Fungsi Kognitif pada Lansia di UPT Panti Werdha Mojopahit. Jurnal Program Studi D-3 Keperawatan STIKES Pemkab Jombang

Muzamil. (2014). Hubungan antara Tingkat Aktivitas Fisik dengan Fungsi Kognitif pada Usila di Kelurahan Jati Kecamatan Padang Timur. Jurnal Kesehatan Andalas,3(2)

Nugroho, Wahyudi. H. (2012). Keperawatan Gerontik \& Geriatrik (Edisi 3). Jakarta: EGC

Pascana, Y. A. (2011). Perbedaan Fungsi Kognitif antara Lansia Insomnia dan Tidak Insomnia di Panti Wredha Dharma Baktu Surakarta. Skripsi, diakses di http://digilib.uns.ac.id pada tanggal 3 Februari 2018

Purwanto. (2009). Manfaat Senam Otak (Brain Gym) dalam Mengatasi Kecemasan dan Stres pada Anak Sekolah. Jurnal Kesehatan, 2(1), 81-90. ISSN 1979-7621

Rosita. (2012). Hubungan antara Fungsi Kognitif dengan Kemampuan Interaksi Sosial pada Lansia di Kelurahan Mandan Wilayah Kerja Puskesmas Sukoharjo

Saryono \& Anggraeni, M. D. (2013). Metodologi Penelitian Kualitatif dan Kuantitatif dalam Bidang Kesehatan. Yogyakarta: Nuha Medika

Sauliyusta, M \& Etty, R. (2016). Aktifitas Fisik Mempengaruhi Fungsi Kognitif Lansia. Jurnal Keperawatan Indonesia, 19(2)

Septianti. (2016). Pengaruh Senam Otak (brain gym) terhadap Tingkat Demensia pada Lansia. Jurnal Keperawatan Notokusumo, 4(1)

Setiawan. (2014). Pengaruh Senam Otak dengan Fungsi Kognitif Lansia Demensia di Panti Wredha Darma Bakti Kasih Surakarta

Smeltzer, C. S. (2001). Buku Ajar Keperawatan Medikal Bedah edisi 8.Jakarta: EGC

Stanley, M. \& Bere, P.G. (2007). Buku Ajar Keperawatan Gerontik (edisi 2). Jakarta: Penerbit Buku Kedokteran EGC

Stanley, M. (2006). Perawatan pada Lansia. Jakarta: EGC

Sularyo, T. S. dan Setyo, H. (2002). Senam Otak. Sari Pediatri, 4(1)

Suparmi. (2010). Studi Meta Analisa: Strategi Rehearsal Dan Memori Jangka Pendek. Jurnal Psikologi, 5(2), 289-310

The U.S Departement of Health and Human Services.(2011). Physical Activity and Health Older Adults. Washington DC: Pennsylvania Avenue

Wahyuniarti, A. (2012). Hubungan antara Hipertensi Dengan Penurunan Fungsi Kognitif pada Lansia di Posyandu Lansia Kelurahan Sumber Sari Malang. Diakses dari http://eprints.umm.ac.id//29763/2/jiptummpp-gdl-anisawahyu28578 pada tanggal 16 Juni 2018

Wardana, M dan Kemil, W. (2017).Variasi Mengajar Guru Ditinjau dari Perbedaan Gender. Diakses dari http://www.apra.umsida.ac.id pada tanggal 3 Februari 2018 
Yuliniarsi, E. (2014). Pengaruh Senam Vitalisasi Otak terhadap Peningkatan Keseimbangan Dinamis pada Lanjut Usia

Yusuf. (2010). Senam Otak Meningkatkan Fungsi Kognitif Lansia. Jurnal Ners, $5(1)$ 